\title{
Opioid modulation of LH secretion in the ewe*
}

\author{
A. N. Brooks†, G. E. Lamming, P. D. Lees $\$$ and N. B. Haynes \\ A.F.R.C. Research Group on Hormones and Farm Animal Reproduction, University of Nottingham \\ Faculty of Agricultural Science, Sutton Bonington, Loughborough, Leics LE12 5RD, and \\ $\S$ Department of Neurology and Neurosurgery, Derbyshire Royal Infirmary, Derby DEI 2QY, U.K.
}

\begin{abstract}
Summary. Administration of opioid agonists and antagonists and measurement of resulting hormone changes were used to study the possible effects of opioids on reproductive function in the ewe. Intravenous administration of the long-acting methionineenkephalin analogue FK33-824 (250 $\mu \mathrm{g} / \mathrm{h}$ for $12 \mathrm{~h})$ to 3 ewes during the follicular phase of the oestrous cycle depressed episodic LH secretion. This effect was reversed by administration of the opiate antagonist naloxone $(25 \mathrm{mg} / \mathrm{h})$ in combination with the FK33-824 treatment; in fact LH secretion was enhanced by the combined regimen. Naloxone $(25 \mathrm{mg} / \mathrm{h}$ for $12 \mathrm{~h}$ ) administered alone to 3 ewes in the follicular phase also enhanced LH secretion. In 3 animals treated with FK33-824 during the follicular phase, progesterone remained basal for 14 days after treatment, suggesting that ovulation was blocked. Jugular venous infusion of naloxone $(25,50$ or $100 \mathrm{mg} / \mathrm{h}$ for $8 \mathrm{~h})$ into 5 ewes during the early and mid-luteal phase of the cycle resulted overall in a significant increase in mean plasma LH concentrations and LH episode frequency.

To investigate whether endogenous opioids suppress $\mathrm{LH}$ release in seasonally anoestrous sheep, naloxone was infused intravenously into mature $(25,50$ or $100 \mathrm{mg} / \mathrm{h}$ for $8 \mathrm{~h})$ and yearling ewes $(12.5,25$ or $50 \mathrm{mg} / \mathrm{h}$ for $8 \mathrm{~h}$ ) during early, mid- and late anoestrus and plasma LH concentrations were measured. In the mature ewes, there was a trend for naloxone to increase $\mathrm{LH}$ values during the early anoestrous period but naloxone was without effect during mid- and late anoestrus. In the yearlings, naloxone infusion consistently increased plasma $\mathrm{LH}$ concentrations as a result of a significant increase in LH episode frequency. These experiments indicate that endogenous opioid peptides probably modulate gonadotrophin secretion during both the follicular and luteal phases of the oestrous cycle. However, the follicular phase of the sheep cycle is of short duration, and there may be residual effects of luteal-phase progesterone during this period. Secondly, there may be an age-dependent effect of naloxone on $\mathrm{LH}$ secretion during seasonal anoestrus in the ewe, with opioids playing a part in the suppression of $\mathrm{LH}$ in young but not in mature animals.
\end{abstract}

\section{Introduction}

It is established now that endogenous peptides with opioid activity appear to modulate gonadotrophin secretion in several species, essentially exerting a suppressive effect. For example, administration of met-enkephalin has been shown to decrease serum luteinizing hormone (LH) in male rats, an effect that was reduced if the opioid was given concurrently with the opiate antagonist naloxone

\footnotetext{
*Reprint requests to Dr N. B. Haynes.

†Present address: Research Institute, St Joseph's Hospital, 268 Grosvenor Street, London, Ontario, Canada N6A 4V2. †Present address: Wessex Neurological Centre, Southampton General Hospital, Shirley, Southampton SO9 4XY, U.K.
} 
(Bruni, Van Vugt, Marshall \& Meites, 1977). Also, naloxone stimulated LH secretion at some ages in immature female rats (Blank, Panerai \& Friesen, 1979). In cyclic women, naloxone treatment increased both plasma LH concentration and the frequency of LH pulses (Ropert, Quigley \& Yen, 1981) and infusion of the met-enkephalin analogue D-Ala ${ }^{2} \mathrm{MePhe}^{4} \mathrm{Met}$ (o)enkephalin-ol (FK33824 ) into post-menopausal women significantly reduced plasma LH concentrations (Grossman $e t$ al., 1981). Furthermore, Quigley \& Yen (1980) have shown that the extent of LH modulation by opioid peptides may vary throughout the menstrual cycle since the human female responds rapidly to naloxone in terms of $\mathrm{LH}$ secretion during the mid-luteal phase of the cycle, but not during the early follicular phase. There is evidence for some species that such changes in sensitivity to naloxone are related to the steroid milieu at the time of administration, because gonadectomized rats became refractory to naloxone and the opioid analogue FK33-824, an effect which was reversed after steroid hormone priming (Bhanot \& Wilkinson, 1983a, 1984). Hypothalamohypophysial portal blood concentrations of $\beta$-endorphin, an index of hypothalamic opioid activity, were reduced in the ovariectomized monkey whilst oestradiol replacement therapy partly restored the levels and oestrogen therapy combined with progesterone was more effective (Wehrenberg, Wardlaw, Frantz \& Ferin, 1982). Opiates do not alter the LH responses to GnRH in the monkey and human (Grossman et al., 1981; Ferin, Wehrenberg, Lam, Alston \& Vande Wiele, 1982), indicating that they exert their actions at a site other than the pituitary, possibly the hypothalamus or in neurones that impinge on the hypothalamus (Drouva, Epelbaum, Tapia-Arancibia, Laplante \& Kordon, 1981; Lakoski \& Gebhart, 1981).

There is no information on the effects of opioids on reproductive function in the ewe, a species of particular interest in this respect since gonadotrophin secretion is naturally suppressed during seasonal anoestrus, an effect thought to be related to changes in sensitivity to steroid feedback (Legan \& Karsch, 1980). The experiments reported here were carried out to determine whether opioid actions similar to those found in other species occur during the oestrous cycle of the sheep and whether opioids may also be involved in the suppression of LH secretion in this species during seasonal anoestrus.

\section{Materials and Methods}

Three experiments were carried out, two during the oestrous cycle and one during seasonal anoestrus.

\section{Oestrous cycle studies}

Experiment 1. This was to determine whether administration of the opioid agonist FK33-824 would suppress LH secretion during the follicular phase of the oestrous cycle when LH concentrations are normally elevated. To this end, and to show that any effect would be specifically through opioid receptors, the drug was administered on its own and in combination with the opioid antagonist naloxone. On the basis of the results obtained, naloxone was also administered alone, to verify that an endogenous opioid mechanism was involved in suppression of $\mathrm{LH}$ during the follicular phase of the cycle.

Experiment 2. This was to ascertain whether naloxone administration would enhance $\mathrm{LH}$ secretion during the luteal phase of the oestrous cycle, a time when $\mathrm{LH}$ values are normally suppressed.

\section{Studies during seasonal anoestrus}

Experiment 3. This experiment investigated whether naloxone would be capable of elevating LH concentrations in seasonally anoestrous ewes, thus providing evidence for an opioid-mediated suppression of $\mathrm{LH}$ at this time. 


\section{Animals and general management}

Twenty-two Suffolk-cross ewes weighing between 36 and $72 \mathrm{~kg}$ were used for experiments conducted during the oestrous cycle and 6 Suffolk yearling non-parous ewes weighing between 43 and $50 \mathrm{~kg}$ and 9 mature Suffolk-cross multiparous ewes weighing between 70 and $75 \mathrm{~kg}$ for the studies during seasonal anoestrus. All ewes were kept at pasture and brought inside for periods of blood sampling. Whilst inside, they were maintained in individual pens under a natural light regimen and given free access to water, hay and a conventional sheep ration. For Exps 1 and 2, oestrous cycles were synchronized by using intravaginal progestagen sponges (Chronogest: Intervet, Science Park, Milton Road, Cambridge, U.K.) inserted at least 12 days before the experiments and removed at the appropriate time as described later for the particular studies. Twice weekly blood samples were taken by jugular venepuncture into vacutainers for periods before and after the various experimental protocols and progesterone measurements were carried out to determine the status of reproductive cycles. In all experiments cannulae were placed in both jugular veins using local anaesthesia and aseptic procedures $24 \mathrm{~h}$ before the start of blood sampling for LH determinations. All infusions were carried out using portable syringe drivers (type MS 16, Graseby Dynamics Ltd, Watford, Herts, U.K.) strapped to the back of the sheep and the naloxone (Sterling Winthrop, Guildford, Surrey, U.K.) or FK33-824 (Sandoz, Basle, Switzerland) was administered dissolved in sterile saline $(0.9 \% \mathrm{w} / \mathrm{v})$ at the appropriate concentrations. Blood $(3 \mathrm{ml})$ was taken at $15-\mathrm{min}$ intervals from the cannula contralateral to that being used for infusion, for various periods of time depending upon the particular experiment. The blood was immediately centrifuged and the plasma stored at $-15^{\circ} \mathrm{C}$ until required for assay. Laparoscopies were performed under pentobarbitone-induced anaesthesia.

\section{Oestrous cycle studies}

Experiment 1 . To study the effects of naloxone upon tonic $\mathrm{LH}$ release during the follicular phase of the cycle, it was necessary to work between the time progesterone falls to basal levels and the onset of the preovulatory LH surge. This period occupies about $37 \mathrm{~h}$ in the natural situation and is some $8 \mathrm{~h}$ shorter when induced, due to the more rapid decline in plasma progesterone after exogenous progesterone withdrawal compared to that during the natural cycle (Haresign, 1985). To investigate the effect of FK33-824 during this time, progestagen sponges were removed from 4 ewes, and, starting $18 \mathrm{~h}$ later, these animals were infused via the jugular vein for $12 \mathrm{~h}$ with FK 33-824 $\left(250 \mu \mathrm{g} / \mathrm{h}, \sim 6.5 \mu \mathrm{g} / \mathrm{kg} \mathrm{h}^{-1}\right)$ at an infusion rate of $2 \mathrm{ml} / \mathrm{h}$. Plasma samples were collected from $12 \mathrm{~h}$ before to $12 \mathrm{~h}$ after infusion. This design, also used in luteal-phase studies (see next section) and consisting of consecutive control, treatment and run-off periods was designed (a) to allow experiments to be conducted over a short time so that the three periods fall effectively at the same stage of the cycle and are hence comparable, and (b) to obtain some information on the short-term persistence of effects after cessation of drug treatments. Immediately after the run-off period, blood samples were taken every $2 \mathrm{~h}$ for $60 \mathrm{~h}$ specifically to monitor the occurrence of a preovulatory LH surge. The ovarian status of the animals was investigated by laparoscopy 3 days after the end of blood sampling. Another 4 ewes were treated with FK33-824 in exactly the same way and in addition given naloxone as a $25 \mathrm{mg}$ bolus $(\sim 0.65 \mathrm{mg} / \mathrm{kg})$ in $2 \mathrm{ml}$ saline $5 \mathrm{~min}$ before the start of FK33-824 treatment and every hour thereafier, with the final injection 5 min before FK33-824 infusion ceased. Each dose of naloxone was administered directly and rapidly via the cannula from which blood samples were taken. All studies involving FK33-824 were carried out in January. In February 4 synchronized ewes were given naloxone as a $25 \mathrm{mg}$ bolus $(\sim 0.65 \mathrm{mg} / \mathrm{kg})$ in $2 \mathrm{ml}$ saline every $\mathrm{h}$ for a 12 -h period, beginning $18 \mathrm{~h}$ after sponge withdrawal.

Experiment 2. Six ewes were infused with naloxone at a rate of 25,50 or $100 \mathrm{mg}(2 \mathrm{ml}) / \mathrm{h} ; 2$ ewes/dose) for $8 \mathrm{~h}$ during the early luteal phase of the cycle ( 7 days after progestagen sponge removal). These doses, which approximate to $0.38,0.75$ and $1.50 \mathrm{mg} / \mathrm{kg} \mathrm{h}^{-1}$, were chosen as a result of preliminary experiments which demonstrated that equivalent amounts of naloxone on an 
approximate weight basis to those used in the human ( 2 and $4 \mathrm{mg} / \mathrm{h}$ ) were ineffective. Blood samples were taken for $8 \mathrm{~h}$ before, during and after $8 \mathrm{~h}$ of naloxone infusion. The experiment was repeated, with the same sheep receiving the same naloxone dose, in the mid-luteal phase of the same cycle (11 days after sponge removal). These experiments were conducted in December. An additional experiment was carried out during the late luteal phase ( 15 days after sponge removal) in the middle of the following January, using the same protocol but with 4 different sheep. These received doses of $50 \mathrm{mg}$ ( 2 sheep) or $100 \mathrm{mg}$ ( 2 sheep) naloxone/h.

\section{Studies during seasonal anoestrus}

Experiment 3. Five mature ewes were infused with naloxone at a rate of 25,50 or $100 \mathrm{mg}$ $(2 \mathrm{ml}) / \mathrm{h}$; equivalent to $\sim 0.35,0.70$ and $1.40 \mathrm{mg} / \mathrm{kg} \mathrm{h}^{-1}$ ( 2 ewes at the $25 \mathrm{mg}$ and $100 \mathrm{mg}$ doses and 1 at $50 \mathrm{mg}$ ) for $8 \mathrm{~h}$ in late April. Four different mature ewes were infused with $50 \mathrm{mg}(2 \mathrm{ml})$ naloxone/h for $8 \mathrm{~h}$ in June and again in August. Six yearlings were infused in early June, July and August with naloxone at $12.5,25$ or $50 \mathrm{mg}(2 \mathrm{ml}) / \mathrm{h}$; equivalent to $\sim 0.27,0.55$ and $1.10 \mathrm{mg} / \mathrm{kg} \mathrm{h}^{-1}$ ( 2 sheep/dose, with the same dose given to the same animal on each occasion).

\section{Hormone assays}

Plasma LH concentration was measured by the specific double-antibody radioimmunoassay as described by McLeod, Haresign \& Lamming (1982). Sensitivity, defined as 2 s.d. from the binding value at zero concentration of $\mathrm{LH}$ was $0.3 \mathrm{ng} \mathrm{NIH-LH-S23} \mathrm{equiv./ml} \mathrm{plasma.} \mathrm{Intra-} \mathrm{and} \mathrm{inter-}$ assay coefficients of variation within this study were $7.9 \%$ and $8.1 \%$ respectively. Progesterone was measured by the method of Haresign, Foster, Haynes, Crighton \& Lamming (1975). The limit of sensitivity was $0.1 \mathrm{ng} / \mathrm{ml}$ plasma and intra- and inter-assay coefficients of variation were $<12 \%$.

\section{Statistical analysis}

An LH episode was defined as a rise in plasma concentration of the hormone greater than $50 \%$

Table 1. Mean plasma LH concentrations and episode frequency for sheep treated with FK33-824, FK33-824 + naloxone or naloxone alone during the follicular phase of the cycle

\begin{tabular}{|c|c|c|c|c|}
\hline & $\begin{array}{l}\text { Control } \\
\text { period } \\
(12 \mathrm{~h})\end{array}$ & $\begin{array}{l}\text { Infusion } \\
\text { period } \\
(12 \mathrm{~h})\end{array}$ & $\begin{array}{l}\text { Run-off } \\
\text { period } \\
(12 \mathrm{~h})\end{array}$ & s.e.d. \\
\hline \multicolumn{5}{|l|}{ FK33-824 (N = 3) } \\
\hline Mean LH conc. $(\mathrm{ng} / \mathrm{ml})$ & $5 \cdot 12 \pm 0 \cdot 58^{\mathrm{a}}$ & $1.97 \pm 0.53^{b}$ & $3.40 \pm 0.99$ & 1.087 \\
\hline Episode frequency $/ 12 \mathrm{~h}$ & $8 \cdot 33(5-10)^{2}$ & $0.67(0-2)^{b}$ & $5 \cdot 33 \overline{(2-8)^{a}}$ & \\
\hline Mean LH episode amplitude $(\mathrm{ng} / \mathrm{m}))^{*}$ & $9 \cdot 52 \pm 2 \cdot 19$ & $1.88 \pm 1.73$ & $6.95 \pm 1.79$ & \\
\hline \multicolumn{5}{|l|}{ FK33-824+ naloxone $(N=4)$} \\
\hline Mean LH conc. (ng/ml) & $7.64 \pm 1.91$ & $9 \cdot 15 \pm 1 \cdot 91^{\mathrm{b}}$ & $5 \cdot 58 \pm 0.97^{\mathrm{c}}$ & 0.942 \\
\hline Episode frequency $/ 12 \mathrm{~h}$ & $9 \cdot 00(6-11)^{\mathrm{a}}$ & $6.75(3-9)^{b}$ & $5.00(4-6)^{b}$ & \\
\hline Mean LH episode amplitude (ng/ml) & $12 \cdot 17 \pm 2 \cdot 95$ & $14 \cdot 70 \pm 3 \cdot 47^{b}$ & $9 \cdot 38 \pm 2 \cdot 00^{c}$ & $1 \cdot 422$ \\
\hline \multicolumn{5}{|l|}{ Naloxone $(\mathrm{N}=3)$} \\
\hline Mean LH conc. $(\mathrm{ng} / \mathrm{ml})$ & $4.45 \pm 0.51$ & $6 \cdot 68 \pm 1 \cdot 14^{b}$ & $4 \cdot 32 \pm 0 \cdot 26^{a}$ & 1.087 \\
\hline Episode frequency $/ 12 \mathrm{~h}$ & $4.67(4-6)^{a}$ & $9 \cdot 00(7-11)^{b}$ & $3 \cdot 33(2-5)^{\mathrm{a}}$ & \\
\hline Mean LH episode amplitude $(\mathrm{ng} / \mathrm{ml})$ & $6.64 \pm 0.74^{\mathrm{a}}$ & $10 \cdot 25 \pm 1.91^{\mathrm{b}}$ & $5.77 \pm 0.53^{\mathrm{a}}$ & 1.642 \\
\hline
\end{tabular}

Across rows: a and b significantly different $(P<0.05)$; b and $\mathrm{c}$ significantly different $(P<0.01)$.

* Since FK33-824 treatment alone abolished the occurrence of LH episodes there is no analysis of episode height in this group. 


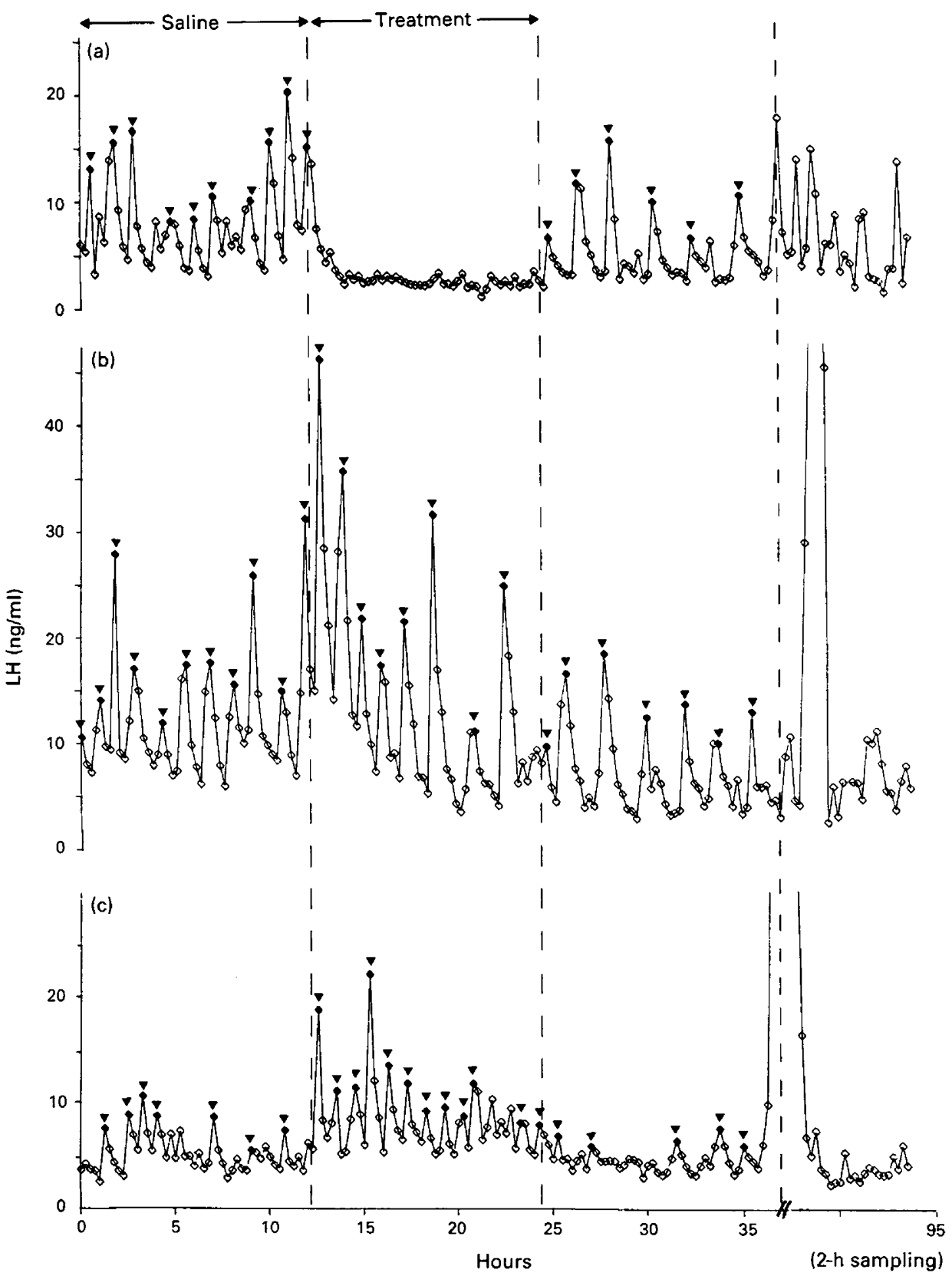

Fig. 1. Plasma LH concentrations in 3 follicular-phase ewes before and in response to an intravenous infusion of (a) $250 \mu \mathrm{g}$ FK33-824/h, (b) $250 \mu \mathrm{g} \mathrm{FK} 33-824 / \mathrm{h}$ in combination with hourly injections of $25 \mathrm{mg}$ naloxone and, (c) hourly injections of $25 \mathrm{mg}$ naloxone alone. The treatment period of $12 \mathrm{~h}$ was preceded by a 12 -h control period during which saline was infused and followed by a 12-h run-off period during which there was no treatment. A period of $60 \mathrm{~h}$ during which blood samples were taken every $2 \mathrm{~h}$ followed the run-off period. LH episodes conforming to the definition used (see text) are indicated by $\boldsymbol{\nabla}$. No such indication is made during the period of $2-\mathrm{h}$ sampling. 
above the preceding baseline value with at least 2 points between the peak value and the succeeding trough (the choice of $50 \%$ was arbitrary, but was more than $4 \times \mathrm{C}$.V. for duplicate pairs in the assay).

Mean LH concentrations and episode heights were examined by a split-plot analysis of variance with animals being regarded as the main plots to which treatments were applied. The treatments were split into a control, treatment and run-off period which constitute the sub-plots of the statistical analysis. Such an analysis produces an overall indication of between- and within-animal variation in the form of a standard error of difference (s.e.d.). This value, along with standard errors for each mean, is presented in Tables 1 and 2.

Analysis of deviance using a Poisson distribution was used to compare discrete data that did not conform to a normal distribution, i.e. episode frequency (Nelder \& Wedderburn, 1972). Standard errors are not given for episode frequencies since their derivation relies on the assumption of a normal distribution. Instead, the mean and range are presented.

\section{Results}

\section{Oestrous cycle studies}

Experiment 1. Plasma LH profiles for 3 ewes given FK33-824 alone, FK33-824 + naloxone, or naloxone alone, are shown in Fig. 1. Mean LH concentration, episode frequency and episode height for all groups are summarized in Table 1. Plasma progesterone concentrations after treatment for all groups are presented in Fig. 2. On the basis of retrospective progesterone data, Ewe 115 was seen not to be in the follicular phase of the cycle during FK33-824 infusion, since progesterone concentrations were still elevated at this time (Fig. 2) and was therefore excluded from statistical analysis. In addition, Ewe S6, given naloxone alone, was excluded from analysis since in retrospect it was shown to have produced an LH surge of ovulatory peak magnitude (values in excess of $50 \mathrm{ng} / \mathrm{ml}$ ) just before naloxone treatment.

Infusion of FK33-824 alone depressed LH secretion by blocking the episodic nature of LH release normally found during the follicular phase. Both mean LH concentration and episode height were significantly $(P<0.05)$ lower during treatment with FK33-824 when compared with the preceding 12-h control period. Episode height was not analysed since FK33-824 abolished the normal episodic LH pattern. A preovulatory-type LH surge (see Martin, 1984) occurred in one ewe about $40 \mathrm{~h}$ after FK33-824 treatment and this animal subsequently showed plasma progesterone concentrations indicative of ovulation and the formation of a normal corpus luteum (Fig. 2, Ewe 147). The other 3 sheep had no preovulatory LH surge and, on the basis of progesterone data, did not apparently ovulate and form normal corpora lutea. Laparoscopy revealed limited follicular development in these ewes.

FK33-824 and naloxone given concurrently resulted in mean $\mathrm{LH}$ concentrations and mean LH pulse heights that were not significantly different between the control and treatment periods, although values for the treatment period tended to be higher. In fact, there was a significant $(P<0 \cdot 01)$ elevation in mean LH concentrations in the first $4 \mathrm{~h}$ of treatment with FK33-824+ naloxone compared with the preceding $4 \mathrm{~h}$ of the control period. LH episodes were present during treatment but with a significantly lower frequency $(P<0.05)$ than during the control period. There were significant reductions $(P<0.05)$ in all three parameters, between the treatment and run-off periods, but not between control and run-off periods. In all ewes treated with FK33-824+ naloxone, a preovulatory LH surge occurred, laparoscopy revealed the formation of macroscopically normal corpora lutea and progesterone secretion appeared normal in the subsequent cycles.

Administration of naloxone alone during the follicular phase of the cycle enhanced mean $\mathrm{LH}$ concentration and significantly $(P<0.05)$ increased the frequency and height of LH episodes. 

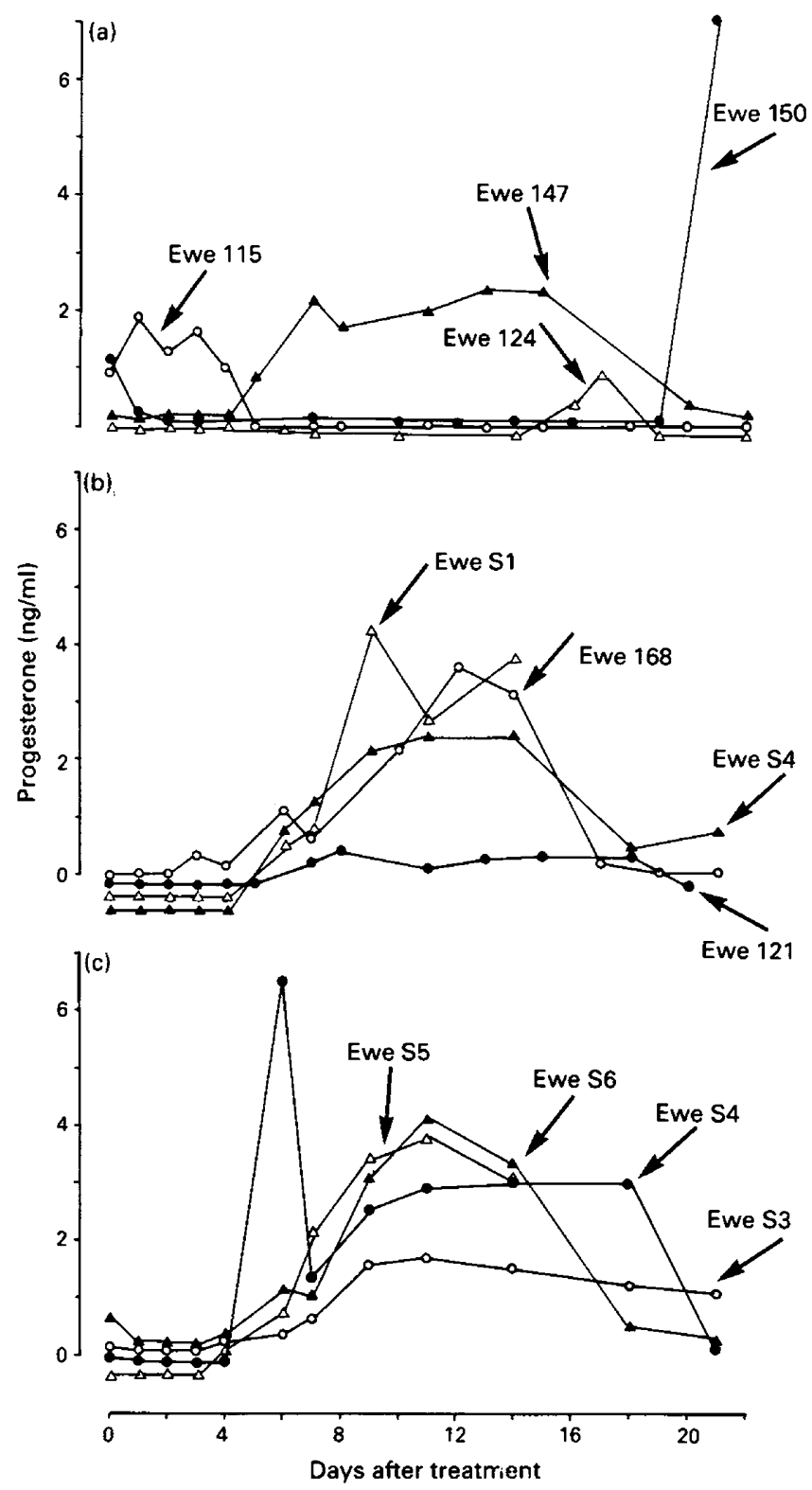

Fig. 2. Plasma progesterone profiles for follicular-phase ewes given (a) FK33-824 alone, (b) FK33-824 + naloxone and (c) naloxone alone.

Although not statistically significant, it appeared that the mean LH concentrations remained elevated for a longer period in the sheep treated with naloxone alone compared with those given FK33-824 + naloxone (see Fig. 1). Mean LH concentration, episode frequency and episode height were significantly reduced between treatment and run-off but not between control and run-off periods. In all ewes treated with naloxone alone a preovulatory LH surge occurred, a corpus luteum was present at laparoscopy and progesterone secretion appeared normal in the subsequent cycles. 
Table 2. Mean plasma LH concentrations, episode frequency and mean LH episode height for sheep treated with naloxone during the early and mid-luteal phase (combined) and late luteal phase of the cycle

$\begin{array}{ccc}\text { Control } & \text { Infusion } & \text { Run-off } \\ \text { period } & \text { period } & \text { period } \\ (8 \mathrm{~h}) & (8 \mathrm{~h}) & (8 \mathrm{~h})\end{array}$

$(8 \mathrm{~h})$

$(8 \mathrm{~h})$

$(8 \mathrm{~h})$

s.e.d.
Early and mid-luteal phase combined $(\mathrm{N}=10)$ Mean $\mathrm{LH}$ conc. (ng/ml)
Episode frequency $/ 8 \mathrm{~h}$
Mean LH episode amplitude $(\mathrm{ng} / \mathrm{ml})$

$1.93 \pm 0 \cdot 19^{\mathrm{a}}$
$1 \cdot 6(0-3)^{\mathrm{a}}$
$6 \cdot 9 \pm 2 \cdot 12$

$6 \cdot 9 \pm 2 \cdot 12$

$1 \cdot 75 \pm 0.37$
$2 \cdot 3(1-3)$
$3 \cdot 88 \pm 0.89$

$2 \cdot 26 \pm 0 \cdot 18^{b}$
$3 \cdot 4(0-5)^{b}$
$5 \cdot 38 \pm 0 \cdot 87$

$1 \cdot 77 \pm 0 \cdot 18^{\mathrm{a}}$

$1 \cdot 0(0-2)^{\mathrm{a}}$

$4.87 \pm 0.97$

0.080

0.698

Late luteal phase $(\mathrm{N}=4)$

Mean $\mathrm{LH}$ conc. $(\mathrm{ng} / \mathrm{ml})$

Episode frequency $/ 8 \mathrm{~h}$

Mean LH episode amplitude (ng/ml)

$1 \cdot 60 \pm 0 \cdot 42$

$1 \cdot 0(0-2)$

$5 \cdot 07 \pm 1 \cdot 57$
0.993

$1 \cdot 238$

Across rows: a and b significantly different $(P<0.01)$.

Experiment 2. Plasma LH concentrations for all naloxone-treated sheep during the early, midand late luteal phase are given in Fig. 3 (1 of the 6 sheep used in the early and mid-luteal phase experiment was subsequently found to be pregnant and is excluded). There were no significant effects of dose, and no differences between treatments carried out in the early and mid-luteal phase so these data have been combined and are summarized in Table 2.

Naloxone treatment resulted in a significant $(P<0.01)$ increase in mean LH concentration and number of LH episodes in these groups compared to the control and run-off periods. There were no significant differences in peak height between any periods. For the late luteal group different animals had to be used and it is for this reason that the data are not combined with those from the early and mid-luteal phases. In this group, there were trends indicative of an effect of naloxone although these did not reach significance (Table 2). Progesterone data for this study confirmed that the animals were in the stated part of the cycle.

\section{Studies during seasonal anoestrus}

Experiment 3. Progesterone determinations in all animals were below the sensitivity of the assay, indicating the absence of active luteal tissue and that the animals were anovulatory. There were no discernible large follicles or corpora lutea at laparoscopy.

LH profiles for yearlings treated with naloxone during early, mid- and late anoestrus are shown in Fig. 4, and those for mature ewes during the same periods in Fig. 5. Data from both types of sheep are summarized in Table 3. For the yearlings naloxone treatment resulted in significant $(P<0.01$ or $P<0.05)$ increases in mean LH concentration, episode frequency and episode height during late anoestrus, only episode frequency $(P<0.05)$ at mid-anoestrus and had no effect on any measure during early anoestrus. Data for the pre-treatment and post-treatment periods were not significantly different, indicating that any effect of naloxone was short-lived.

It is evident (see Fig. 4) that there is marked variability in the LH response between individual yearlings ranging from the moderate increase in $\mathrm{LH}$ seen in Ewe 184 during mid- and late anoestrus to Ewe 187 which did not respond at any period. For the mature ewes, there were no signiticant effects of nuloxone on LH although the trends towards increased LH secretion and episode frequency in the early anoestrous group approached significance at the $5 \%$ level. 

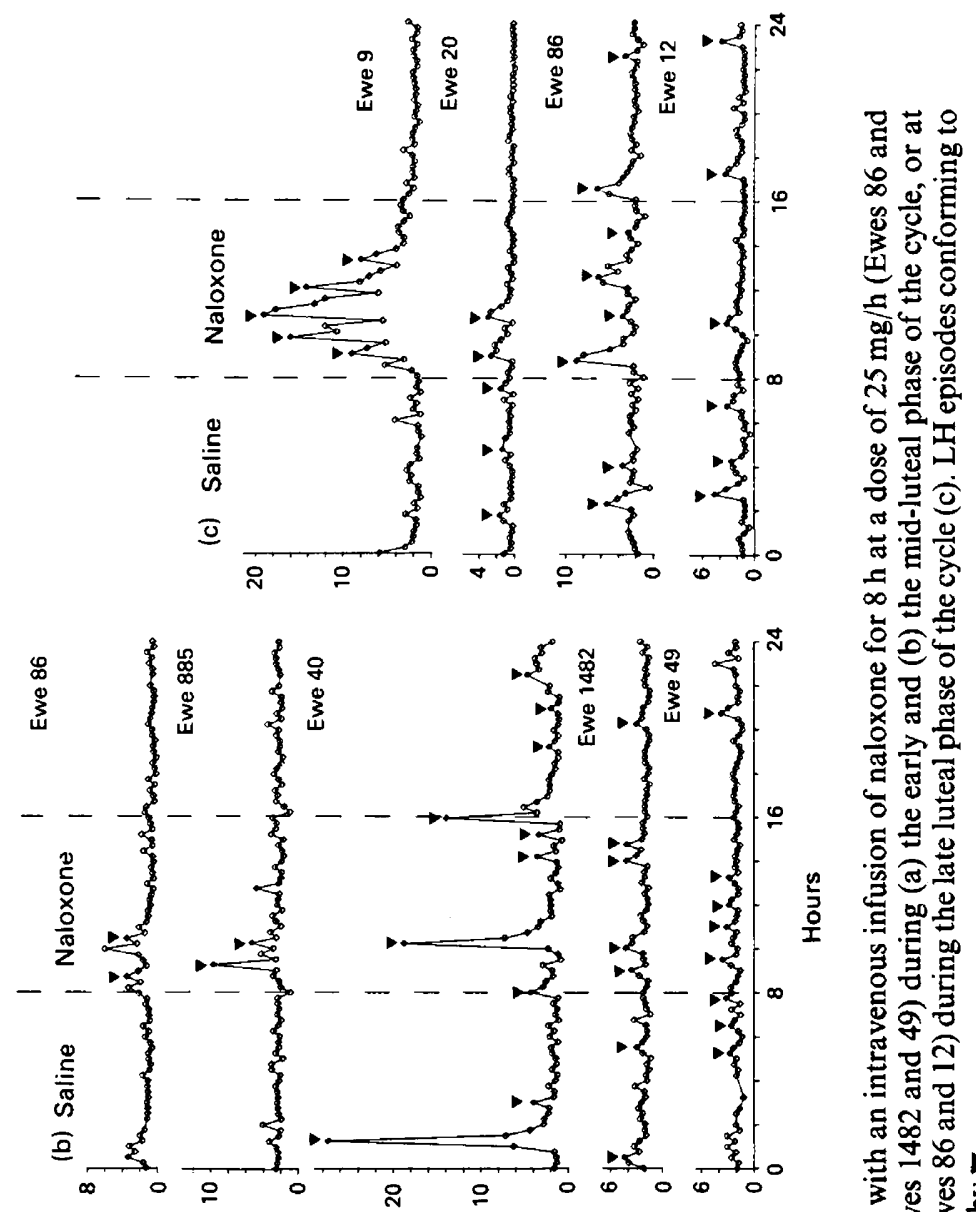

응

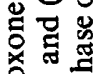
늠 氙芯 을

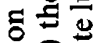
쥬 일올 约 을 号 $\stackrel{8}{8}$ 壱 穴 잉 됴 $\infty$

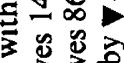
总岂出导

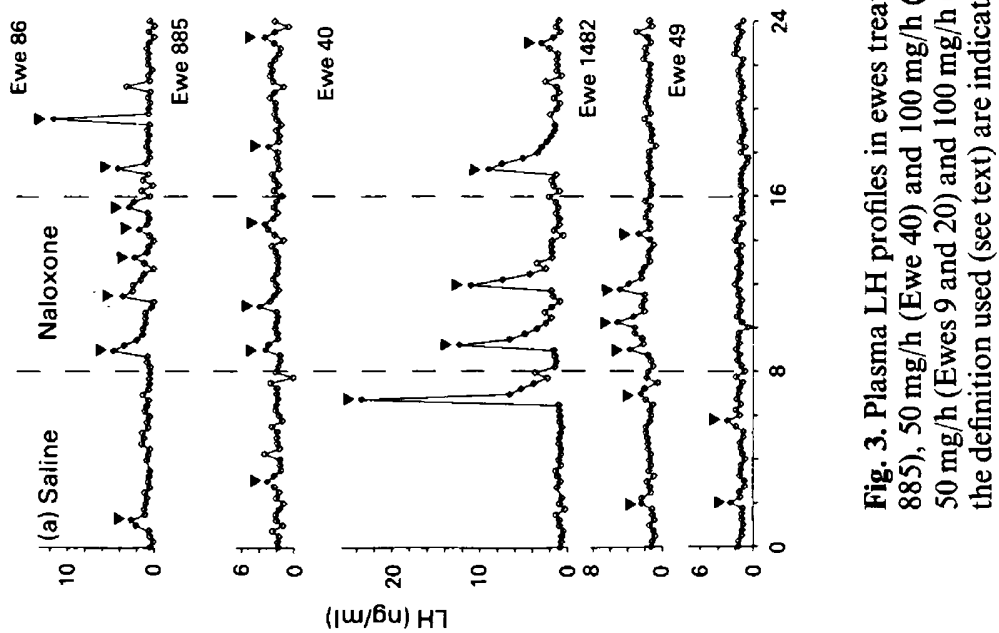


A. N. Brooks et al.

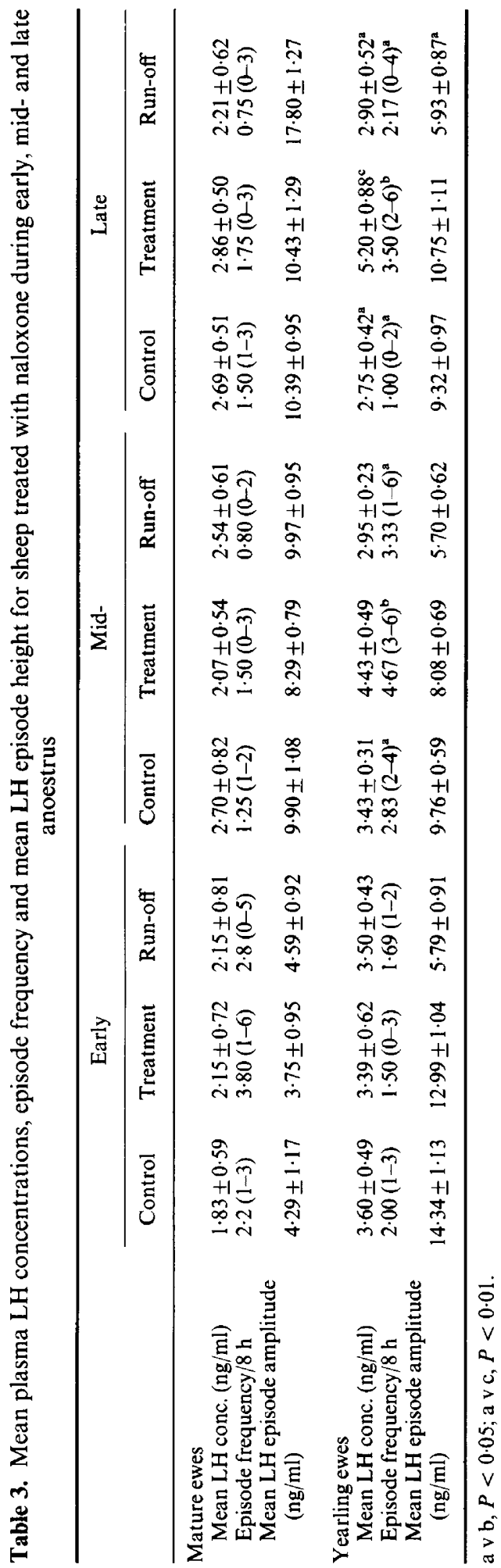




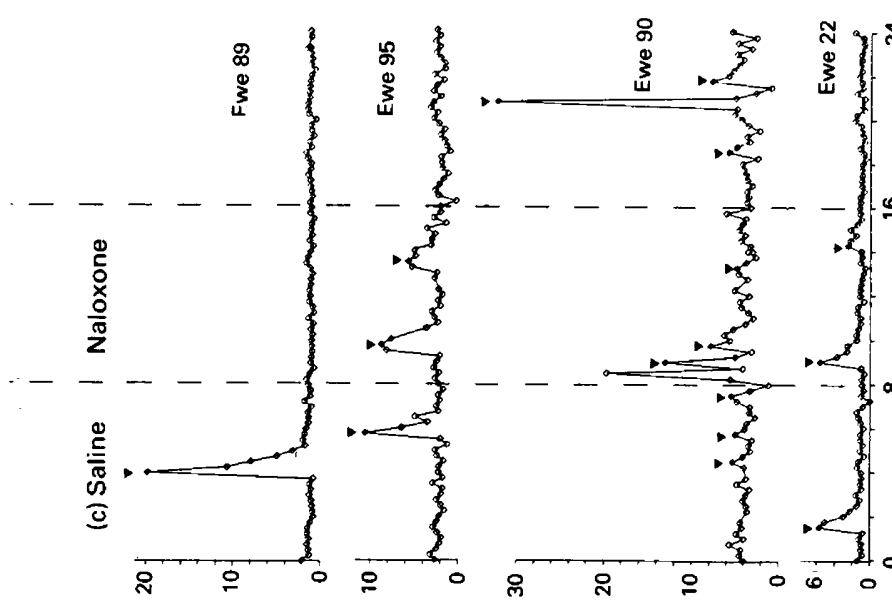

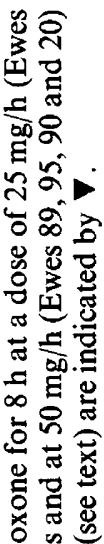



\section{Discussion}

Infusion of the long-acting met-enkephalin analogue FK33-824 blocked pulsatile LH secretion during the follicular phase of the oestrous cycle. When naloxone was administered concurrently, the effect of FK33-824 was removed, as demonstrated by the presence of LH pulses (with a frequency somewhat lower but amplitude higher than in the control period) and a tendency towards higher mean LH concentrations during treatment compared with the control period. This suggests that the effect of FK33-824 is mediated specifically through opioid receptors, primarily to depress LH episode frequency through an action on the neurogenic pulse generator system (Jackson, 1977; Peet \& Lincoln, 1977; Kalra \& Simpkins, 1981). Furthermore, the tendency towards an increase in LH concentration during the combined treatment results from a significant increase at the beginning of treatment which gradually declined during the treatment period (see Fig. 1 and 'Results'). This suggests a degree of endogenous opioid suppression of $\mathrm{LH}$ during the follicular phase of the cycle, with the initial action of naloxone being to remove both the effect of the endogenous opioid and the exogenous drug; ultimately the action of naloxone at the dose used would be overridden by a build up of FK33-824. This possibility of endogenous opioid action during the follicular phase is given further support by the significant increase in LH concentrations and pulse frequency found over the whole treatment period when naloxone alone was administered. These observations, together with the stimulatory action of naloxone during the luteal phase, suggest that endogenous opioid peptides may exert a modulating effect on $\mathrm{LH}$ in the cyclic ewe and are essentially suppressive; in this respect the ewe accords with other species, namely the rat, human and monkey (Bruni et al., 1977; Ropert et al., 1981; Ferin et al., 1982).

Subtle changes in LH secretion before the ovulatory surge in the ewe are of paramount importance in the development of optimum follicular growth and subsequent luteal function (McLeod et al., 1982, 1983) and cyclic changes in opioid action may therefore have an important role in maintaining normal cyclic activity in sheep. This is supported by the observation that infusion of FK33-824 prevented the formation of a normal corpus luteum for the duration of at least one cycle in 3 out of 4 ewes, presumably due to the lack of a preovulatory LH surge and hence lack of ovulation. There is good evidence that morphine administration on the afternoon of pro-oestrus will block ovulation in the rat (Barraclough \& Sawyer, 1955; Pang, Zimmermann \& Sawyer, 1977), an effect mediated via a suppression of the pro-oestrous surge of GnRH (Ching, 1983). If the situation in the sheep is similar, it would seem that, since FK33-824 blocks both pulsatile LH secretion and the preovulatory LH surge, this represents either a general inhibitory effect of FK33-824 upon GnRH release or a specific effect on two distinct neural mechanisms.

These findings do differ, however, from those with women in which, during the early follicular phase, naloxone was ineffective, suggesting no endogenous opioid activity at this time. Naloxone enhanced LH secretion during the luteal phase in sheep and humans (Quigley \& Yen, 1980; Ropert et al., 1981) with the response appearing somewhat more pronounced in the latter. The implication from the human studies is that a progesterone and/or oestrogen milieu may be necessary for opioid action and the difference between the species may be because of the short follicular phase in the sheep, which ovulates about $48 \mathrm{~h}$ after the cyclic demise of the corpus luteum. To make sure the experimental animals were in the follicular phase, treatment began only $18 \mathrm{~h}$ after removal of the progestagen-secreting sponge and there may well be some residual receptor-bound progestagen at this time.

The ewe studies also differ from those of the human (but not rats and hamsters) with respect to the systemically administered dose of naloxone apparently necessary to block the effects of opioids upon LH since the amounts given to ewes were 6-20-fold higher on a weight basis than the human dose and the response produced was less dramatic. Also, Schanbacher (1985) and G. A. Lincoln (personal communication) have reported that high doses of naloxone are necessary to stimulate LH secretion in the ram. Whether this represents a fundamental difference between sheep and humans in opioid concentration or receptor population sensitivity, or a difference in ability of 
naloxone to reach the target site is not established. Much higher doses on a weight:weight basis of exogenous opiates such as fentanyl are required to induce anaesthesia in sheep compared to humans (Illius et al., 1983).

The necessity to use such high levels of naloxone also raises the question as to whether the observed effects are a result of some non-specific action of the drug. We cannot answer this directly. However, we have also carried out experiments using a new opioid antagonist WIN 44441-3 (Sterling Winthrop; Ward, Pierson \& Michne, 1983) which has structural similarities to naloxone. Again, high doses were needed to produce results equivalent to those reported for naloxone. The readily available (+)-enantiomer of WIN 44441-3 had no effect upon LH concentrations, providing evidence that for WIN 44441-3 the effect upon LH secretion is specifically mediated through opioid receptors (Brooks, Haynes \& Lamming, 1986).

It is apparent that naloxone treatment, although inducing a significant increase in LH secretion overall, resulted in a variable increase between animals particularly in luteal-phase studies (Fig. 3). Similar findings have also been reported for the monkey in which only $60 \%$ of animals treated with naloxone exhibited a statistically significant rise in $\mathrm{LH}$ values during the luteal phase of the menstrual cycle (Van Vugt, Bakst, Dyrenfurth \& Ferin, 1983). Furthermore, there was no indication in this work of synchrony of LH release as a result of naloxone administration as shown in the human by Quigley \& Yen (1980). These findings may reffect different threshold levels of opioid-induced inhibition of LH secretion with some animals responding to the dose of naloxone given and some not.

For the seasonally anoestrous mature ewes, with the exception of a trend towards an elevation in LH during the early anoestrous period, there were no effects of naloxone, a situation different from that found during the oestrous cycle. These data can be interpreted in a number of ways. Firstly, the photoperiodic mechanisms by which LH is suppressed during seasonal anoestrus are without opioid peptide involvement; another non-opioid inhibitory system becoming operational, the effects of which are not reversed by naloxone. Secondly, the level of endogenous opioid activity may be so high that it cannot be counteracted, notwithstanding the high doses of naloxone used. The design of this experiment does not answer this question and, indeed, it is difficult to see reliable ways of addressing this problem. A possibility would be to compare brain levels of opioid peptides and opioid receptors between the breeding and non-breeding seasons.

There is considerable evidence that an elevated progesterone environment is required for naloxone to be effective in stimulating LH secretion. For instance, during the early follicular phase in women, when plasma concentrations of this steroid are basal, naloxone is ineffective in raising plasma levels of LH (Quigley \& Yen, 1980; Blankstein, Reyes, Winter \& Faiman, 1981; Snowden, Khan-Dawood \& Dawood, 1984). However, maximum responses to naloxone are achieved during the luteal phase of the cycle (Quigley \& Yen, 1980). This is supported by studies which demonstrated that treatment of the ovariectomized monkey with a progesterone/oestrogen combination resulted in a marked increase in $\beta$-endorphin concentrations in hypothalamic portal vein blood (Wardlaw, Wehrenberg, Ferin, Autunes \& Frantz, 1982). If mature sheep are similar, then the lack of progesterone during seasonal anoestrus could account for the lack of an effect of naloxone. There is tentative support for this from the fact that there is a trend towards an elevation in $\mathrm{LH}$ concentrations during naloxone infusion in the early anoestrous group, which, it is assumed, had been recently cycling and hence experienced elevated progesterone values not long before treatment.

Our data are in agreement with recent findings for the hamster in which short-days (nonbreeding season) remove the otherwise good response to naloxone seen during long days (Eskes, Wilkinson \& Bhanot, 1984). This is currently the only evidence which directly supports the findings here that, in mature ewes, naloxone loses its ability to stimulate LH secretion during seasonal anoestrus. On the other hand, the yearling animals behaved differently and naloxone treatment caused significant elevations in LH secretion. The response, moreover, was apparently greater at mid- and late anoestrus than in the early anoestrous period so these animals apparently do not 
require any recent progesterone priming. We currently have no explanation for the difference. Because of the variability in increase of LH release between yearling sheep, it may be that the yearlings are in an age-related transition state between response and non-response, particularly since age has been reported to have a marked influence upon the response of other species to naloxone. For instance, naloxone treatment reversed the short photoperiod-induced suppression of $\mathrm{LH}$ in prepubertal and young post-pubertal (5-6 months old) hamsters, but was ineffective in reproductively more mature animals 1 year of age (Chen, Targovnik, McMillan \& Randall, 1984). Also, in the rat naloxone-induced $\mathrm{LH}$ increases have been shown to be greatest in the prepubertal female rat, but to diminish as the animal reaches adulthood (Blank et al., 1979). Furthermore, FK33-824 administration inhibited $\mathrm{LH}$ secretion in gonadectomized prepubertal female rats and the response showed an age-related decline (Wilkinson \& Bhanot, 1982; Bhanot \& Wilkinson, 1983b).

As stated above, the lack of an LH response to naloxone in mature ewes may be due to a non-opioid inhibitory neuronal system which is activated during seasonal anoestrus. If activation of this system was also age-dependent this would explain the ability of naloxone to stimulate LH secretion in some yearling ewes when only an opioid system is operating, but not in mature ewes when the opioid-independent pathway is activated. Furthermore the yearling ewes have an elevated LH pulse frequency compared with that of the mature ewes during the control periods, an observation which could also be explained by such a mechanism.

In conclusion, evidence is presented in support of the theory that opioids play a part in the control of LH secretion in the cyclic ewe. However, we have been unable to demonstrate that endogenous opioids have major physiological significance in the seasonally induced suppression of LH secretion in the mature ewe. Nevertheless, the results presented for yearling sheep add to the current evidence that changes in the magnitude of opioid action may play a physiological role in the modulation of $\mathrm{LH}$ secretion in the young animal.

We thank Dr R. Carter of Sterling Winthrop for the supply of naloxone, and Dr R. Maurer of Sandoz, Basle, for providing FK33-824; the Agricultural \& Food Research Council for financial support; NIH for LH; and the University of Nottingham for the award of a post-graduate scholarship (A.N.B.).

\section{References}

Barraclough, C.A. \& Sawyer, C.H. (1955) Inhibition of the release of pituitary ovulatory hormones in the rat by morphine. Endocrinology 57, 329-337.

Bhanot, R. \& Wilkinson, M. (1983a) Opiatergic control of LH secretion is eliminated by gonadectomy. Endocrinology 112, 399-401.

Bhanot, R. \& Wilkinson, M. (1983b) Opiatergic control of gonadotrophin secretion during puberty in the rat: A neurochemical basis for the hypothalamic 'gonadostat'? Endocrinology 113, 596-603.

Bhanot, R. \& Wilkinson, M. (1984) The inhibitory effect of opiates on gonadotrophin secretion is dependent upon gonadal steroids. J. Endocr. 102, I33-141.

Blank, M.S., Panerai, A.E. \& Friesen, H.G. (1979) Opioid peptides modulate luteinizing hormone secretion during sexual maturation. Science, N.Y. 203, 1129-1131.

Blankstein, J., Reyes, F.I., Winter, J.S.D. \& Faiman, C. (1981) Endorphins and the regulation of the human menstrual cycle. Clin. Endocr. 14, 287-294.

Brooks, A.N., Haynes, N.B. \& Lamming, G.E. (1986) Opioid peptides modulate luteinizing hormone secretion throughout the oestrous cycle in the ewe. $J$. Physiol., Lond. 371, $221 P$.
Bruni, J.F., Van Vugt, D., Marshall, S. \& Meites, J. (1977) Effects of naloxone, morphine and methionine enkephalin on serum prolactin, luteinizing hormone, follicle stimulating hormone, thyroid stimulating hormone and growth hormone. Life Sciences 21, $461-466$.

Chen, H.J., Targovnik, J., McMillan, L. \& Randall, S. (1984) Age difference in endogenous opiate modulation of short photoperiod-induced testicular regression in golden hamsters. J. Endocr. 101, 1-6.

Ching. M. (1983) Morphine suppresses the proestrous surge of $\mathrm{GnRH}$ in pituitary portal plasma of rats. Endocrinology 112, 2209-2211.

Drouva, S.V., Epelbaum, J., Tapia-Arancibia, L., Laplante, E. \& Kordon, C. (1981) Opiate receptors modulate LHRH and SRIF release from mediobasal hypothalamic neurones. Neuroendocrinology 32, $163-167$.

Eskes, C.A., Wilkinson, M. \& Bhanot, R. (1984) Short-day exposure eliminates the LH response to naloxone in golden hamsters. Neuroendocrinology 39, 281-285.

Ferin, M., Wehrenberg, W.B., Lam, N.Y., Alston, E.J. \& Vande Wiele, R.L. (1982) Effects and site of action of 
morphine on gonadotrophin secretion in the female rhesus monkey. Endocrinology 111, 1652-1656.

Grossman, A., Moult, P.J.A., Gaillard, R.C., Delitala, G., Toff, W.D., Rees, L.H. \& Besser, G.M. (1981) The opioid control of $\mathrm{LH}$ and FSH release: effects of a met-enkephalin analogue and naloxone. Clin. Endocr. 14, 41-48.

Haresign, W. (1985) Comparison of the rate of decline in plasma progesterone concentrations at a natural and progesterone-synchronized oestrus and its effect on tonic LH secretion in the ewe. J. Reprod. Fert. 74, 231-236.

Haresign, W., Foster, J.P., Haynes, N.B., Crighton, D.B. \& Lamming, G.E. (1975) Progesterone levels following treatment of seasonally anoestrous ewes with synthetic LH-releasing hormone. J. Reprod. Fert. 43, 269-279.

Illius, A.W., Haynes, N.B., Lamming, G.E., Howles, C.M., Fairall, N. \& Millar, R.P. (1983) Evaluation of LH-RH stimulation of testosterone as an index of reproductive status in rams and its application in wild antelope. J. Reprod. Fert. 68, 105-112.

Jackson, G.L. (1977) Effect of adrenergic blocking drugs on secretion of luteinizing hormone in the ovariectomized ewe. Biol. Reprod. 16, 543-548.

Kalra, S.P. \& Simpkins, J.W. (1981) Evidence for noradrenergic mediation of opioid effects on luteinizing hormone secretion. Endocrinology 169, 776-782.

Lakoski, J.M. \& Gebhart, G.F. (1981) Attenuation of morphine's depression of serum luteinizing hormone by lesions in the amygdala. Neuroendocrinology 53, $105-111$.

Legan, S.J. \& Karsch, F.J. (1980) Photoperiodic control of seasonal breeding in ewes: modulation of the negative feedback action of oestradiol. Biol. Reprod. 23, $1061-1068$.

Martin, G.B. (1984) Factors affecting the secretion of luteinizing hormone in the ewe. Biol. Rev. 59, 1-87.

Mcleod, B.J., Haresign, W. \& Lamming, G.E. (1982) The induction of ovulation and luteal function in seasonally anoestrous ewes treated with small-dose multiple injections of Gn-RH. J. Reprod. Fert. 65, 215-221.

McLeod, B.J., Haresign, W. \& Lamming, G.E. (1983) Induction of ovulation in seasonally anoestrous ewes by continuous infusion of low doses of Gn-RH. $J$. Reprod. Fert. 68, 489-495.
Nelder, J.A. \& Wedderburn, R.W.M. (1972) Generalized linear models. Jl R. statist. Soc. A 135, 370-384.

Pang, C.N., Zimmermann, E. \& Sawyer, C.H. (1977) Morphine inhibition of the preovulatory surges of plasma luteinizing hormone and follicle stimulating hormone in the rat. Endocrinology 101, 1726-1732.

Peet, M.J. \& Lincoln, G.A. (1977) Blockade of episodic gonadotrophin secretion by Immobilon in ovariectomized ewes. J. Reprod. Fert. 50, 97-100.

Quigley, M.E. \& Yen, S.S.C. (1980) The role of endogenous opiates on $\mathrm{LH}$ secretion during the menstrual cycle. J. clin. Endocr. Metab. 51, 179-181.

Ropert, J.F., Quigley, M.E. \& Yen, S.S.C. (1981) Endogenous opiates modulate pulsatile luteinizing hormone release in humans. $J$. clin. Endocr. Metab. 52, 583-585.

Schanbacher, B.D. (1985) Endogenous opiates and the hypothalamic-pituitary-gonadal axis in male sheep. Domestic Animal Endocrinology 2, 67-75.

Snowden, E.U., Khan-Dawood, F. \& Dawood, M. (1984) The effect of naloxone on endogenous opioid regulation of pituitary gonadotrophins and prolactin during the menstrual cycle. J. clin. Endocr. Metab. 59, 298-302.

Van Vugt, D.A., Bakst, G., Dyrenfurth, I. \& Ferin, M. (1983) Naloxone stimulation of luteinizing hormone secretion in the female monkey: influence of endocrine and experimental conditions. Endocrinology 113, 1858-1864.

Ward, S.J., Pierson, A.K. \& Michne, W.F. (1983) Multiple opioid receptor profile in vitro and activity in vivo of the potent opioid antagonist WIN 44441-3. Life Sci. 33 (Suppl. 1), 303-306.

Wardlaw, S.L., Wehrenberg, W.B., Ferin, M., Autunes, J.L. \& Frantz, A.G. (1982) Effect of sex steroids on $\beta$-endorphin in hypophyseal portal blood. J. clin. Endocr. Metab. 55, 877-881.

Wehrenberg, W.B., Wardlaw, S.L., Frantz, A.G. \& Ferin, M. (1982) $\beta$-Endorphin in hypophyseal portal blood: variations throughout the menstrual cycle. Endocrinology 111, 879-881.

Wilkinson, M. \& Bhanot, R. (1982) A puberty-related attenuation of opiate peptide-induced inhibition of LH secretion. Endocrinology 110, 1046-1048.

Received 24 July 1985 